\title{
Restructuring the Plea Bargain
}

Few features of our criminal process have been so disfavored and yet so durable as plea bargaining. Despite misgivings about both its wisdom and its constitutionality, and calls for its abolition, ${ }^{1}$ the practice shows no sign of vanishing: the guilty plea still accounts for an overwhelming majority of our criminal dispositions. ${ }^{2}$

The continued prevalence of plea bargaining signifies that the arguments against it have proven unequal to the administrative rationale in its favor. ${ }^{3}$ So long as it remains impossible for our criminal system to permit every defendant to claim his right to a jury trial, some inducements for the surrender of that right will be necessary. At the moment, plea bargaining is our only vehicle for granting such inducements. Moreover, absent a dramatic increase in legal resources or the appearance of some other strategy which compensates for our shortage of those resources, plea bargaining is likely to endure.

Nevertheless, the present bargaining process may be neither the only nor the most equitable way to induce a large volume of guilty pleas." It may be possible to attain the administrative goals of plea bargaining at less cost to the interests of both the defendant and the public. This Note contends that the present bargaining process is incompatible with enlightened and fair sentencing policy because it arbitrarily favors some classes of defendants and fails to generate the information which

1. Many commentators have decried the inequitable aspects of plea bargaining. See A. Blumberg, Criminal Justice (1967); Rossett, The Negotiated Guilly Plea, 874 Annals 70 (1967); Note, The Unconstitutionality of Plea Bargaining, 83 HAkv. L. REv. 1987 (1970).

2. Guilty pleas comprise over ninety per cent of all dispositions in some jurisdictions, particularly criminal courts in large metropolitan areas sttch as New York. S'ee 'l'itE President's Commission on Law ENforcement and the Administration of Justici', 'I'ask FORCE REPORT: THE COURTS 9 (1967). In the federal system, the volume of guilty pleas remained constant at around seventy per cent during the period 1967.68. Sec Aunual Report, Director of the Administrative Office of the United States Courts in REl'ORTS O1: THE Proceedings of the Judicial, Conference of the UNITEd States 261 (1968).

3. The Supreme Court has apparently found the administrative rationale for plea bargaining compelling. In Brady v. United States, 397 U.S. 742 (1970), the Court held that plea bargaining does not violate the Fifth Amendment. Recently, the Court inter alia reaffirmed its Brady holding in Santobello v. New York, 92 S. Ct. 495 (1971).

$B$ rady and Santobello can be viewed as the culmination of a long serics of lower court rulings upholding the constitutionality of plea bargaining. See, e.g., Lassiter v. Furncr, 423 F.2d 897 (4th Cir. 1970); Brown v. Beto, 377 F.2d 950 (5th Cir. 1967); Barber v. Gladden, 327 F.2d 101 (9th Cir. 1964); United States v. Hughes, 325 F.2d 789 (2d Cir. 1964); Martin v. United States, 256 F.2d 345 (5th Cir. 1958).

4. Accepting the inevitability of plea bargaining, several commentators now advocatc not its abolition but its reform. See, e.g., Tentative Standards Relating to Pleas of Guiltyaba Project on Minimum Standards for Criminal Justice (1967); Enker, perspectives on Plea Bargaining in The President's Commission on LAW ENFokCeMEN' Ministration of JuSTICE, TASK Force REPORT: THE Courts 108 (1967); White, proposal for the Reform of Plea-Bargaining, 119 U. PA. L. REv. 439 (1971). 
any criminal system needs to make intelligent dispositions. It is the argument of this Note that this sentencing failure is attributable to two factors: (1) the absence of a regularized advocacy procedure which would impose rigor and consistency on the determination of plea-concessions, and (2) the inability of the judge to oversee the formulation of plea agreements.

This Note therefore urges the elimination of unregulated "bargaining" between the defendant and the prosecutor. In its place, the Note proposes restructuring the pre-plea stage of the criminal process to include an advocacy proceeding in which the judge exercises full responsibility for the concessions the defendant receives in exchange for his plea.

\section{The Failures of the Current Bargaining Process}

\section{A. Plea Bargaining as a Sentencing Decision}

Both appellate courts and scholarly commentators have tacitly considered the plea bargaining process the sole preserve of defense and prosecution. Judicial participation in the process-at least before the defendant tenders his plea-has been viewed with nearly universal distaste. ${ }^{5}$

5. The scholarly literature on plea bargaining reflects an almost total hostility to judicial participation in the bargaining process. See, e.g., ABA STAND.Anos, supra noic 4, at 3.3; White, supra note 4, at 452-53; Note, Unconstitutionality, supra note I, at 1392; Recent Development, 19 STAN. L. REv. 1082, 1089 (1967). Virtually the only commentator favoring an expanded judicial role in plea bargaining is Enker, supra note 4.

The court decisions, however, present a somewhat more complicated picture. They have frequently distinguished between judicial threats and judicial concessions, as the $y^{*}$ may affect pre-plea bargaining. The judge who threatens hardship to a defendant for exercising his right to trial has been universally condemned. See Aiken v. United States, 296 F.2d 604 (4th Cir. 1961); United States v. Lester, 247 F.2d 496 (2d Cir. 1957); Euziere v. United States, 249 F.2d 293 (10th Cir. 1957); Letters v. Commonvealth, 340 MIass. 403, 193 N.E.2d 578 (1963).

Concessions offered by a judge prior to entry of the plea have been vieved more favorably than judicial threats. See Brown v. Peyton, 435 F.2d 1352 (4th Cir. 1970); United States ex rel. Rosa v. Follette, 395 F.2d 721 (2d Cir. 1968); United States ex rel. McGrath v. Lavallee, 319 F.2d 308 (2d Cir. 1963).

Nevertheless, the clear weight of authority seems to condemn judicial concessions as well. See Worcester v. Comm'n of Internal Revenue, 370 F.2d 713 (Ist Cir. 1905) (dieta): United States ex rel. Elksnis v. Gilligan, 356 F. Supp. 244 (S.D.N.Y. 1960): IfcClure v. Boles, 233 F. Supp. 928 (N.D. W. Va. 1964) (dicta); People v. Earegood, 12 Alich. App. 256, 162 N.W. 802 (1968); Rogers v. State, 136 So. 2 d 331, 243 Miss. II9 (1962); Commonwealth v. Evans, 434 Pa. 52, 253 A.2d 689 (1969); Commonwealth ex rel. Kreckes :. Moroney, $423 \mathrm{~Pa}$. 337, 223 A.2d 699 (1966) (dicta).

If, however, the judge merely states his sentencing inclination and avoids any express sentencing assurance, his conduct is felt to be less reprozchable. Sec, e.g., United States ex rel. MfG Grath v. Lavallee, 319 F.2d 308, 314 (2d Cir. 1963).

The judge may also consult with the prosecutor alone to explore whether his negotiating position is satisfactory to the court. Or prior to the entry of the plea, the judge may" confer with both prosecutor and defense counsel, again to consider the suitability of 
This insistence on insulating the bargaining process from judicial intrusion reflects a widespread misconception of plea bargaining's rolc in a criminal proceeding. Plea bargaining is commonly characterized as a strategic rather than an adjudicative or a sentencing activity. ${ }^{\circ}$ Its purpose is believed to be the negotiated surrender of the defendant's procedural rights in return for tactical concessions uniquely within the discretion of the prosecutor to grant. ${ }^{7}$ It is generally assumed that the calculation of the costs and risks of litigation and the subsequent choice of litigation strategy are tasks which the parties themselves are best qualified to perform. If the defendant wishes to waive his procedural rights, the courts will customarily feel bound to respect his tactical judgment-provided, of course, that this judgment is not the product of undue coercion or misinformation. ${ }^{8}$ Likewise, if the partics to at litigation, civil or criminal, voluntarily agree to limit the issues they will contest before the court, the judge will feel similarly bound to defer to their tactical decision to forego adjudication. ${ }^{0}$

Unlike the typical procedural waiver, however, the guilty plea constitutes much more than a selection of strategy which the defendant

the plea bargain they have independently conceived. The former practice secults faitly widespread. See Note, Guilty Plea Bargaining: Compromise by Prosecutors to Sccure Guilty Pleas, 112 U. PA. L. Rev. 865, 906 (1964). The latter practice apparently occurred in United States ex rel. Rosa v. Follette, 395 F.2d 721 (2d Cir. 1968) and was there ap. proved. It is also the prevailing procedure in the Kings County, New York Criminal Court, see Krantz, An Evaluation of the Kings Cotnty l'Iea Negotiation Conference Pro. gram, 1971 (unpublished manuscript prepared for CJCC, Boston University Liw School); and in Illinois, see Mills, The Prosecutor: Charging and Bargaining, 1066 1L.. L. Rev. 511,519 (1966). The ABA STANDARDS, supra note 4, at $3.3(b)$, gives this form of judicial participation qualified approval, although recommending that such participation uccur only at the initiative of the defendant.

Despite the dim view that appellate judges take of virtually all forms of preplea judicial intervention, there is evidence that it is a surprisingly widespread practice among trial judges. Some 32.9 per cent of the prosecutors interviewed in thirty states indicated that the judge was involved in some phase of the bargaining process. Se' Note, Guilty Plea Bargaining, supra at 905. At the very least, this statistic suggests a disparity in the perspectives from which trial and appellate judges regard plea bargatining.

6. Brady v. United States, 397 U.S. 742,752 (1970), used language suggestive of this approach when it justified plea bargaining by stressing its "mutuality of atlvantage" for defense and prosecution.

7. In Scott v. United States, 419 F.2d 264 (D.C. Cir. 1969), Judge Bazclon apparcntly endorsed this concept of plea bargaining as a legitimate exchange of tactical concessions:

When there is substantial uncertainty concerning the likely outcounc of a trial, each side is interested in limiting those inherent litigation risks. '1he prosecuto' may be willing to accept a plea of guilty on a lesser charge rather than chatuce an acquittal on the more serious. The accused may be similarly willing to acknowl. edge his guilt of the lesser charge rather than risk conviction on the more scrious charge, or to accept the promise of a lighter sentence to escape the possibility of conviction after trial and a heavier sentence.

Id. at 276 (footnote omitted).

8. The Court in Brady v. United States, 397 U.S. 742 (1972), although divided, was in agreement on the proposition that courts should disturb the results of plea bargaining only when the prosecutor "unfairly burden[s] or intrude[s] upon the defendant's decision. making process." Id. at 802 (Brennan, J., dissenting). See note 69 infra.

9. See Rossett, supra note 1 , at 79 . 
will then employ in the formal adjudication of his guilt. Instead, it completely ends that adjudication and makes the defendant's guilt a settled legal fact. Moreover, as the product of a plea bargain, the defendant's guilty plea also embodies an assessment of his culpability, the moral gravity of his conduct, his danger to society and the punishment which the social and individual dimensions of his case require. The plea bargain, therefore, not only preempts the duty of the judge to adjudicate the defendant's guilt or innocence in concert with the jury; it also preempts the duty of the judge to sentence the convicted defendant. ${ }^{10}$

\section{B. The Methodology of Effective Sentencing}

Since plea bargaining performs a sentencing function, it must be evaluated according to its ability to generate dispositions that comport with accepted sentencing standards. To undertake that evaluation, it is first necessary to examine the principles of effective sentencing.

For the past few decades, penologists and legal scholars have advocated individualized sentencing as the most enlightened method of disposition for convicted defendants. ${ }^{11}$ Individualized sentencing looks for sentencing criteria to the totality of the defendant's circumstancesto the detailed facts of his crime and to his criminal and personal biography. ${ }^{12}$

10. Enker, supra note 4 , at $109-10$, is alone among the critics of plea bargaining in his concern for its erosion of judicial sentencing authority.

11. See Rubin, Disparity and Equality of Sentences-A Constitutional Challenge. 10 F.R.D. 55 (1966), for an exposition of the principles and goals of individualized sentencing. See also Bennett, Countdown for Judicial Sentencing, Fed. Probatios, Sept. 1961, at 2f; Levin, Toward a More Enlightened Sentencing Procedure, 45 NEu. L. REv. 499 (1969).

12. Glueck, Predictive Devices and the Individualization of Justicc, 23 LAW ANo CosTEMP. Prob. 461, 461 (1958), outlines this approach:

[T]o "individualize" the sentence in the case of any specific offender means first, 10 differentiate him from other offenders in personality, character, sociocultural background, the motivations of his crime, and his particular potentialities for relorm or recidivism; and, secondly, to determine which, among a range of punitise, corrective, psychiatric and social measures, is best adapted to solve the special set of problems presented by that offender in such a way as matcrially to reduce the probability of his committing crimes in the future.

Legislatures have responded to these theories by enacting sentencing statutes which vest broad discretion in the judge. Many jurisdictions now grant wide judicial discretion in the setting of minimum and maximum sentences; others have introduced indeterminate sentencing. For a survey of these statutory policies, see D. GLASEn, F. CoIIE: \& V. O'Leary, The Sentencing and Parole Process 9-15 (1960). Coupled with this increase in judicial discretion is the effort to permit probation and parole boards as vell as prison authorities to revise judicial sentencing decisions. "Administrative sentencing" is especially prevalent in California, Washington, Oregon, Missouri and Minnesota. In these states, the parole board or a sentencing administration sets the minimum sentence at the conclusion of an observational period which follows judicial commitment. See Hayner, Sentencing by an Administrative Board, 23 LAW AND CoNTEMr. Prod. 477-91 (1958). 
Coupled with this commitment to individualized sentencing, there has been an emerging concern for fair sentencing procedure. Both the courts and penologists have stressed the orderly flow of relevant information into the sentencing process and the procedural rights of the defendant as that process unfolds. ${ }^{13}$ Not only has the penological value of the pre-sentence report been increasingly stressed; ${ }^{\mathbf{1 4}}$ there is also growing agreement that its contents must be divulged to the defendant, who can then dispute either its factual accuracy or its broader hypotheses about his behavior. ${ }^{15}$ In theory, both prosecution and defense should use this report as authority for their sentence recommendations; occasionally, the defense may even elaborate on its sentence recommendation in the form of a detailed treatment proposal.10 Such "sentencing due process" is considered valuable not just because it helps achieve responsible sentencing, but also because it demonstrates the state's con-

13. The ascendancy of the sentencing hearing has been accompanicd by a growing concern for the procedural regularity of sentencing procedures. Attention has focuscd on the right to counsel at sentencing proceedings-a right apparently granted in Mimplia v. Rhay, 389 U.S. 128 (1967), where the Court designated sentencing as a "critical stage" of the defendant's case. In Oyler v. Boles, 368 U.S. 448 (1962), the Court implied that a defendant must receive reasonable notice and the opportunity to be heard prior to sentencing. Moreover, there is emerging case law guarantecing the defendant the right to speak in his own behalf and to introduce evidence at the sentencing hearing. Sec Pugh \& Carver, Due Process and Sentencing-From "Mapp" to "Mempha" to "McGautha," 49 TEXas L. REv. 25 (1970). Furthermore, many commentators urge judicial cxposition of the reasons for the sentences imposed, see Rubin, supra note 11, at 72; Frankel, Th/ Sentencing Morass and a Suggestion for Reform, 3 CRIM. L. BuLL. 365 (1967); and ap. pellate review of sentencing, see Rubin, supra note 11, at 74; DeCosta, Disparily and III. equality of Criminal Sentences: Constitutional and Legislative Approaches to A ppellate Review and Reallocation of the Sentencing Function, 14 How. L.J. 29 (1968); Hruska, Appellate Review of Sentences, 8 AM. CRIM. L.Q. 10 (1969).

On the general subject of sentencing procedure, sec K. DAvis, Discretrosakr Jusilck 133-41 (1967) and Cohen, Sentencing, Probation and the Rehabilitative Ideal; The T'iew From "Mempha v. Rhay," 47 TeXas L. Rev. 1 (1968).

14. On the pre-sentence report generally, see Note, The Presentence Reporl: An Empirical Study of its Use in the Federal Criminal Process, 58 Geo. L.J. 451 (1970).

D. Newman, Conviction: Determination of Guilt or InNocence W'ThHour 'I'kial 14 (1966) notes that some jurisdictions employ the pre-sentence report as an additionat check of the defendant's guilt and the trustworthiness of his guilty plea.

15. Despite Williams v. New York, 337 U.S. 241 (1969), disclosure of the pre-scntence report is becoming an accepted procedure. The practice was mandated for the fifth Circuit in Smith v. United States, 223 F.2d 750 (5th Cir. 1955), and several state courts now require it as well. For the current arguments for and against disclosture, sce Bach, The Defendant's Right of Access to Pre-sentence Reports, 3 CRIM. L. BuLL. 674 (1967).

16. Such a use of the pre-sentence report contemplates tranforming the sentencing hearing into an advocacy hearing, with defense counsel offering a comprehensive antysis of the defendant's character, criminality and treatment prospects. It has becn observed that it therefore envisions a radically altered concept of the defense counsel-onc hard to square with his traditional adversarial role. See Kadish, The Advocate and the Lixpert -Counsel in the Peno-Correctional Process, 45 Mins. L. Rev. 803 (1961). Kadish believes that it is valuable for the defendant himself to take an active role in debating the punisli. ment he will receive; a view apparently adopted by the A.B.A. ABA 1'rojkcir on MiNI. mum Standards for Criminal Justice, Sentencing Alternatives and Procedures 254.55 (1967). A recent program in the Washington, D.C. Criminal Courts has demonstrated the value of rehabilitative planning by the defendant, his counsel and social agencies. Sec Dash, Medalic \& Rhoden, Demonstrating Rehabilitative Planning as a Defense Strutcgy, 54 Cornell L. Rev. 408 (1969). 
cern for the defendant's fate after conviction. This demonstration of concern, in turn, begins to define for the defendant-and induces him to define for himself-the treatment goals which the state hopes his incarceration will accomplish.

\section{The Inadequacies of Plea Bargaining as a Sentencing Process}

\section{Indifference to Sentencing Data}

In its present form, plea bargaining is irreconcilable with this model for orderly and enlightened sentencing decisions. ${ }^{17}$ Since it is a disguised sentencing procedure, ${ }^{18}$ the plea bargain often makes the sentencing hearing an idle formality; by the time it occurs, the prosecutor, the defendant and the judge may lack both the inclination and the effective power to revise the sentence which the plea bargain has tacitly fixed. Therefore, the sentencing process is deprived of the portrait of the defendant which the sentencing hearing is supposed to assemble. ${ }^{10}$ The pre-sentence report, as well as the detailed presentation of the defendant's crime and character which ideally should emerge from his trial, contains critical sentencing data which the parties will neglect to consider during the bargaining process but which later may cast doubt on the wisdom of the plea bargain. ${ }^{20}$

\section{Causes of Sentencing Disparity}

The factors which do determine the sentencing outcomes of plea bargaining are totally devoid of genuine penological significance.

17. Only a few commentators have noticed the incompatibility between plea bargaining and the schemes for sentencing reform. See, e.g., Ohlin \& Remington, Sentencing Structure: Its Effect on Systems for the Administration of Criminal Justice, 23 LAw \& ConteMp. ProB. 495, 499-500 (1958).

18. Enker, supra note 4, at 110. See also Rossett, supra notc 1, at $71-72$, who argues that the results of plea bargaining systematically lack congruence with "the specific charges of the case, the correctional needs of the defendant, and frequently, the social interest in vigorous prosecution."

19. Efforts to gather adequate correctional data-both at the plea bargaining and other stages of the criminal process-have also been inhibited by such factors as the paucity of correctional resources, see President's Comsission on LAw ENFoncesiest AND THE ADMINISTRATION OF JUSTICE, TASK FORCE REIORT: CoRrections 18-19 (I907) and the characteristic mentality of defense lawyers themselves. Polstcin. How to Sellle a Criminal Case, Prac. LAw, Jan., 1972, at 35, 41, notes the failure of most lawyers to mahe any kind of correctional evaluation of their clients, even when it might aid in obtaining a more favorable plea bargain. And Enker, supra note 4, at 111 , asserts that the defense counsel rarely investigates the defendant's background because he views his role not as a "welfare worker" but as an advocate.

20. As a possible response to this problem, Krantz, supra note 5. urges that the presentence report be completed before plea negotiations commence. But pre-sentence investigation before conviction has been opposed on constitutional and policy grounds. See Note, The Presentence Report, supra note 14, at 465-70. 
Three factors now exert a controlling influence on the concessions a defendant will receive and hence the sentence he will eventually serve: the evidential strength of the case against him, the number and seriousness of the charges that his conduct will support, and the wealth and resources at his command. ${ }^{21}$ Collectively, these factors cause wide variation in the penal treatment which equally culpable defendants receive. Ultimately, they breed an unhealthy cynicism among dcfendants and thus contribute to their rejection of the penal system's treatment goals.

\section{a. Strength of the Prosecution's Case}

When his evidence is weak, the prosecutor will propose generous bargaining terms in order to overcome the defendant's inclination to go to trial. ${ }^{22}$ When, on the other hand, the prosecutor's evidence is strong, he will offer few plea concessions since the defendant whose chance for acquittal is slight will need only a small inducement to renounce his right to trial. One reason that the prosecutor adopts this strategy is that he shares the administrative goal of the entire plea bargaining system: the elimination of the maximum number of trials. But another reason is that he wants to protect his conviction record. Since no prosecutor wants to go to trial and lose, it is in his interest to deter from trial those defendants whose acquittal is most probable."

Plea concessions reduced to reflect the defendant's chances for acquittal defeat two major goals which any enlightened criminal system must pursue: reliable adjudication and uniform sentencing. The defendant against whom the prosecutor's case is weak will either be guilty beyond a reasonable doubt of the acts alleged or he will be legally innocent. ${ }^{24}$ If he is guilty, sentencing uniformity requires an appro-

21. An additional factor is the degrec of administrative strain that the court is experiencing at the particular moment. Polstein, supra note 19, suggests, at 10 , thit defense counsel can rely on an "almost mathematical rule that the more crowded the calendar, the lower the plea." He notes the very real risk that too prolonged a delity between indictment and trial can make the prosecutor vulnerable to a motion to dismiss.

22. Alschuler, in The Prosecutor's Role in Plea Bargaining, 36 U. Cits. L. REv. 50 (1968), expresses a typical view when he asserts, at 58, that "[t]he overwhelming majority of prosecutors view the strength or weakness of the state's casc as the most important factor in the task of bargaining," and, at 60, that the "greatest pressures to plead guilty are brought to bear on defendants who may be innocent."

23. See Polstein, supra note 19, at 37 , who contends the prosecutor's obsession with his conviction rate derives from the way the public evaluates his performance. Compare Skolnick, Social Control in the Adversary System, $11 \mathrm{~J}$. OF Conflicr RES. 52 (1967), in which a study of a particular prosecutor's office revealed that the explanation for this preoccupation was the desire "to maintain ... a reputation for utter credibility, incvi. table truth, almost of invincibility." Id. at 57. See generally Alschuler, supra noto 22.

24. Legal innocence, it should be stressed, must not be cquated with factual in. nocence. In the current plea bargaining process, not all defendants whose conviction proves difficult are factually innocent. The case against them may be weak beciltse 
priately severe sanction, i.e., one equivalent to the punishment received by other offenders who have committed similar crimes. On the other hand, if he is innocent, he should be excluded altogether from the correctional process. By compromising somewhere between the only two penologically acceptable classifications of the defendant, the bargaining process results in the imposition of either excessive or insufficient punishment.

Whether it extends the right to trial to all or merely a few defendants, any criminal system must strive to distinguish accurately between those defendants who have committed crimes and those who have not. The current bargaining process seriously impairs our system's ability to make that distinction. By tempting the defendant who is most probably innocent with the greatest concessions, it discourages a trial in precisely those instances when only a trial can make a reliable determination of guilt or innocence. ${ }^{2 \sigma}$

\section{b. Overcharging}

Observers of the prosecutor's bargaining strategy have noted that the initial charges he files are frequently chosen in anticipation of the plea bargain. ${ }^{20}$ The prosecutor often attempts to sweep within his indictment every offense which the evidence against the defendant might sustain. If the single criminal act of the defendant straddles several offense categories, the prosecutor will charge the defendant with the most serious offense applicable, knowing that the offense for which he can realistically expect conviction is a "lesser included offense" encompassed therein. ${ }^{2 \tau}$ Similarly, if the defendant's criminal activity

a police investigation has blundered, because a key witness can be casily impeached or has fled the jurisdiction, or because crucial cvidence has been supprexed. Similarly. the prosecutor may lack confidence in his case because the defendani's demeranor will impress the jury or because his conduct contains extenuating features which sould influence the jury to vote for acquittal. Despite their actual guilt, acquittal of such defendants is perfectly consonant with our belief that punishment is warranted only when guilt has been proven beyond a reasonable doubt. It would be tundesirable for a plea bargaining system to undermine the integrity of the reasonable doubt standard by convicting defendants whose conduct does not mect it.

25. Alschuler, supra note 22, at 62-63, suggests that the ideology of the prosecutor may explain the bargaining process' insensitivity to the possibility of a defendant's innocence:

It might be supposed that when a prosecutor decides to charge a defendant with a crime, he makes a personal judgment concerning the defendant's guilt or in: nocence. Once the charge decision has been made, the prosecutor may regard trial as a technical obstacle standing between the defendant and the punishment he deserves.

26. In a manual for prosecuting attorneys, the Department of Justice has candidly advised: "One method of encouraging such a [guilty] plea is to charge a felony at the outset and in this way set the stage for subsequent bargaining." H. SUbis, U.S. DEpartaient of Justice, Criminal Justice in Mietrololitan Courts 3 4-3j (1960).

27. This practice has been termed "vertical overcharging" by Alschuler, supra note 22 , at 86. 
is technically severable into a series of identical crimes, the prosecutor will charge him with several counts of the same offense. ${ }^{28}$ By charging the defendant at the statutory limit of his liability, the prosecutor is able to generate incentives for the plea bargain. This techniquefrequently termed "overcharging"-permits the prosecutor to bargain away several counts of his indictment or accept a plea to the least serious offense charged without risking an acquittal."o

Overcharging compounds sentencing disparity because defendants vary appreciably in their ability to perceive the practice and adjust their bargaining strategy to compensate for it. A defendant who is ignorant of the prosecution's case or who receives only perfunctory advice from counsel may agree to plea "concessions" no more lenient than the disposition he would receive if he were convicted after trial. Since, by definition, the "overcharge" includes counts on which either the jury would acquit or the judge would impose a concurrent sentence, such a defendant will exchange his plea for illusory benefits. In contrast, the defendant who has better counsel, more knowledge of the prosecution's case, or merely greater familiarity with the behavior of the trial court, will refuse to bargain until the prosecutor's terms become more favorable than the court's foreseeable sentence. Although both defendants may have committed equivalent crimes, the more knowledgeable defendant will serve a substantially shorter sentence. ${ }^{30}$

\section{c. The Defendant's Wealth}

Disparities in wealth and resources are another cause of unequal access to plea concessions. The defendant's wealth influences his ability to make bail and the kind and quality of legal defense he can afford.

If the defendant cannot make bail, the prosecutor will enjoy a substantial bargaining advantage over him. ${ }^{31}$ Already incarcerated, this

28. Alschuler, supra note 22, at 87 , terms this "horizontal overcharging."

29. See generally Enker, supra note 4, at 109-10; Freedman, The Professional Ri. sponsibility of the Prosecuting Attorney, 55 GEo. L. REv. 1030, 1035.96 (1967); Ncwman, supra note 14 , at 98.99 .

Overcharging also complicates the task of correctional administrators who must make subsequent decisions about the defendant's fate. Because many plea bargains result in charge compromises, any attempt to infer the actual criminality of the defculant from the offense for which he was convicted is highly unreliable. Without a record of the defendant's trial, with its detailed account of his crime, or a knowledge of local plea bargaining practices, treatment decisions are subject to a wide margin of error.

30. D. Newman, supra note 14, at 46. In another article, Pleading Guilly for Con. siderations: A Study of Bargain Justice, 46 J. CRIm. L., C. \& P.S. 780, 785 (1956), Newman has observed that it is usually the recidivist who is best able to recognize and obtain a good plea bargain.

31. On bail and plea bargaining, see White, supra note 4 , at 444 . On bail reform generally, see Foote, The Coming Constitutional Crisis in Bail: I, 113 U. PA. L. Rev. 959 (1965). 
defendant has little opportunity to prepare evidence to be used either at trial or as a bargaining lever against the prosecutor. Moreover, each additional day he lingers in jail weakens his desire to withhold his plea and makes him more receptive to the prosecutor's offer. In contrast, the bailed defendant can gradually maneuver the prosecutor into an advantageous plea agreement without serious discomfort.

A wealthy defendant can also retain his own counsel rather than depend on the public defender. When he bargains for a guilty plea, private counsel is usually free from the administrative pressure which plagues both the prosecutor and the public defender. ${ }^{32}$ He will therefore have the time and funds to research his client's case. In sharp contrast, the public defender-who usually cannot employ pre-plea discovery to gather evidence ${ }^{33}$-must frequently accept the prosecution's claim for his case at face value.

Because of both his less intimate relationship to the prosecutor ${ }^{3 t}$ and his greater fund of time and resources, the private attorney can employ a host of bargaining tactics which are generally unavailable to the public defender. ${ }^{35}$ The prosecutor may resort to comparable tactics. He may attempt to "bluff" the defense lawyer by exaggerating the strength of his case or feigning intractability when he has reached an impasse in plea negotiations. ${ }^{30}$ Occasionally, these bargaining techniques frustrate the interests of both parties by backing them into a trial which they do not want and from which they cannot hope to gain. ${ }^{37}$

32. Nonetheless, there are many private attorneys whose resourees barely cxcced those of the public defender. It is probably most accurate to conccive of the community of lawyers as a continuum with the public defender and highly paid private attomey at each extreme and, in between, lawjers of intermediate resources and time to devote to their clients.

33. At present, no jurisdiction appears to authorize defense discovery prior to the entry of a plea, as a matter of either statutory right or judicial discretion. 'The practice in the federal system is typical; Rule $16(f)$ of the Federal Rules pernits discovery no carlier than ten days after arraignment. See generally Comment, Preplea Discovery: Guilty Pleas and the Likelihood of Conviction at Trial, 119 U. PA. L. REY. 527 (1971).

34. Some critics of the public defender system have contended that the relationship of the public defender and prosecutor is non-adversarial. According to this viewpoini, the public defender will often cooperate in a bargained disposition which sacrifices the interests of the defendant in order to serve the common administrative objectives of the public defender and the prosecution. See, e.g., Casper, Did You Have a Lawyer IV'hen You Went To Court? No, I Had A Public Defender, I Yale Rev. L. \& Soc. Acr. 4 (1970); Skolnick, supra note 23 , at $60-70$.

35. In his efforts to consume the prosecutor's time, the private attorney may, for example, deluge the court with pre-trial motions, or resort to any pretext to gain a continuance. He may even request the impaneling of a jury and begin trial if his other tactics have not yet yielded the plea concessions he secks.

36. On bluffing, see Alschuler, supra note 22, at 56.57; Polstein, supra note 19, at 40-41; Rossett, supra note 1, at 71-72.

37. See Alschuler, supra note 22 , at 58 . 


\section{Judicial Control Over the Current Bargaining Process}

At present, the judge is largely precluded from correcting the sentencing disparities that the bargaining process produces. He enters the process only after the bargain has been made, and then only to conduct a superficial oral examination of the defendant to satisfy him. self that the resulting guilty plea is "voluntary"38 and "intelligent"'sv and (in some jurisdictions) that it has a "factual basis." 40 Since this examination ${ }^{41}$ is limited to disclosure of negotiating procedure, judicial consideration of the actual bargain, and the sentencing decision it embodies, is deferred until the sentencing hearing. At that hearing, however, serious modification of the bargain is unlikely. If the judge disregards the prosecutor's sentencing recommendation and imposes a harsher sentence, he will be ordering a disposition that does not conform to the defendant's expectations in accepting the plea bargain.4"

38. On voluntariness and the guilty plea, sec generally Brady v. United States, 397 U.S. 742 (1970); Machibroda v. United States, 368 U.S. 487 (1962); Walcy v، Johnston, 316 U.S. 101 (1942); Walker v. Johnston, 312 U.S. 275 (1941). For compilations of the federal and state law on voluntariness, sec Chalker, Judicial Myopiu, Differenliul Sent. tencing and the Guilty Plea-A Constitutional Examination, 6 AM. Cк1M. L.Q. 187 (1968) and Note, Guilty Plea Bargaining, supra note 5.

39. Von Moltke v. Gillies, 332 U.S. 708 (1948), offers a detailed list of the requisitc elements for an understanding waiver of counsel prior to receipt of a guilty plea:

To be valid, such waiver must be made with an apprehension of the nature of the charges, the statutory offenses included within them, the range of allowable pinish. ments themselves, possible defenses to the charges and circumstances in mitigation thereof and all other facts essential to a broad understanding of the whole inatler. 332 U.S. at 724. The exact application of Von Moltke to the guilty plea itsclf is uII. certain. The courts have found it difficult to delineate both the range of penalties of which the defendant must be aware and the requisite depth with which he must comprehend them. It is agreed, however, that a defendant must understand the nature of the charge to which he is admitting his guilt, Dorrough v. United States, 385 F.2d 887 (5th Cir. 1967), and the terms of his eligibility for probation, Munich v. United States, 337 F.2d 356 (9th Cir. 1964). No consensus exists, however, on whether he must also comprehend the more remote, collateral consequences of his conviction. See Natc, Guilty Plea Bargaining, supra note $\mathbf{5}$, at 875 , for a summary of the case law with regard to such collateral consequences of conviction as multiple offender liability and civil dis. abilities.

40. See Fed. R. Crim. P. 11 and ABA Srandards, supra note 4, at 1.6 (recommcindlug universal adoption of the factual basis requirement). See generally Note, T'/he Trial Judge's Satisfaction as to the Factual Basis of Guilty Pleas, 1966 Wastitncion U. L.(.). 306 (1966).

41. Since Boykin v. Alabama, 395 U.S. 238 (1969), and McCarthy v. United States, 394 U.S. 459 (1969), the judge cannot omit these inquiries in the exercise of his discre. tion; if they are not made, the defendant's plea is automatically void.

42. Even when the judge intervenes in the bargaining process itsclf, he may not be able to escape the hazards of awarding plea concessions which, at the sentencing hearing, will seem unduly lenient. Illustrating this danger are two of the principal cases which concern judicial participation in plea bargaining, United States ex rel. Elksnis v. Gllligall, 256 F. Supp. 244 (S.D.N.Y. 1966), and United States ex rel. McGrath v. LaVallce, 319 1:2d 308 (2d Cir. 1963). In Gilligan, after learning that the defendant was not, as he had assumed, a first felony offender, the judge violated a sentencing commitment hic had made to the defendant during plea negotiations. And, in LaVallee, the trial judgc, who had assured the defendant of leniency, imposed a 20-30 year sentence when he learned the full facts of the defendant's "vicious record." In both cases, the absence of sen. 
And if he overrules the prosecutor too often, defendants as a group will become less inclined to negotiate their guilty pleas. Alternatively, if the judge allows the defendant to withdraw his plea because he cannot countenance its terms, his decision will necessitate renegotiation of that plea and occasionally even a trial. Faced with these eventualities, both incompatible with the administrative rationale for plea bargaining, the judge will usually choose to ratify the bargain automatically. Moreover, judicial review of plea terms when the defendant offers his plea cannot compensate for the judge's inability to correct sentencing inequalities. ${ }^{43}$ Rejection of plea terms at this stage of the bargaining process will require a wasteful renegotiation of the plea bargain. More importantly, the judge usually functions in an informational vacuum when he receives the plea. Without the benefit of a presentence report, trial observation of the defendant, or exposure to the evidence against him, the judge cannot gauge the approprinteness of the bargained disposition. Ignorant of the defendant's case, he may have no choice but to acquiesce in that disposition until the sentencing hearing.44

In the rare instance when the judge decides to supersede the prosecutor by imposing a harsher sentence than the prosecutor recommended, the defendant will understandably feel victimized by factors beyond his control. ${ }^{45}$ At present, such a defendant is without remedy; a reviewing court will probably consider his grievance the product of the tactical uncertainty unavoidable in plea bargaining and deny him

tencing information during negotiations led the judge to sentencing commituments he could not later conscionably honor.

43. A few jurisdictions have introduced this practice. See, e.g., leople v. West, 3 Cal. 3d 595, 91 Cal. Rptr. 385, 477 P.2d 409 (1970), in which the California Supreme Court required the terms of all plea bargains to appear in the court record. For an illuminating discussion of West and its implications, see Comment, Judicial Supervision outer California Plea-Bargaining-Regulating the Trade, 59 CALIf. L. Rev. 962, 980 (1971).

The Kings County, New York, Criminal Court has a similar procedure, sec Krantz, supra note 5 , and the ABA has recommended its general adoption, see AB.1 StaNDikns, supra note 4, at 3.1.

Critics of the present bargaining process have consistently argued that similar expansions of the post-plea duties of the judge are the best remedy for the defects of that process.

The ABA Standards, supra note 4, are typical. While discouraging, at 3.3. pre-plea judicial participation, they advocate expanded judicial examination of the defendant after his plea, at 1.4 and 1.5 , and expanded inquiry into the factual basis of the defendant's plea, at 1.6. Similar proposals appear in Gentile, Fair IJargains and Accurate Pleas, 49 B.U.L. REv. 514, $514-23$ (1969); White, supra note 4, at 462-65; Comment, Judicial Supervision, supra, at 995; Preliminary Draft of Proposed Amendment to the Federal Rules of Criminal Procedure: Rule II (April 1971), reprinted at 52 F.R.D. 109 (1971).

44. See p. 291 supra.

45. Of course, the prosecutor's sentencing recommendation can also crr on the side of harshness. If it does, the judge need not worry that adjusting the sentence downward would result in unfairness to the defendant. However, he still may be reluctant to dis. regard the recommendation. To do so may undermine the prosecutor's credibility in the eyes of defendants and thus indirectly reduce the efficiency of the bargaining process. 
the opportunity to tender a new plea. ${ }^{46}$ In reality, however, such in. equities are not the result of strategic errors for which the defendant, like any other disappointed litigant, should accept responsibility. Instead, they reflect a major imperfection of the current bargaining process: the judge's effective abdication of his sentencing authority to the prosecutor, subject to intermittent reassertions of that power which the defendant can in no way foresee. ${ }^{47}$

\section{E. The Defendant's Perceptions of the Bargaining Process}

The most serious shortcoming of plea bargaining as a sentencing process is the negative perceptions which it encourages defendants to form of the legal system. Sentencing inequalities are widely publicized and compared among inmates, ${ }^{48}$ accentuating the outrage of the defendant who feels he has been misled into accepting an excessively harsh sentence and reinforcing the smugness of the defendant who has bargained for an unduly light sentence. Both defendants derive the same lesson from sentencing disparities: the bargaining process responds to adept manipulation, not to neutral and consistent sentencing principles. ${ }^{49}$

Defendants are also demoralized by the furtive and summary methods that the bargaining process employs. Pleas are often the product of brief and clandestine consultations between the prosecutor and defense counsel which may occur in the courthouse corridor or the prosecutor's office. The defendant rarely attends these consultations, let alone participates in them. And the judge frequently pretends that

46. Holding that an unfulfilled expectation of leniency, even if inspircd by counscl, is not a valid ground for plea withdrawal are: Meredith $v$. United States, 208 F.2d 680 (4th Cir. 1953); Futterman v. United States, 202 F.2d 185 (D.C. Cir. 1952); In re Atchley, 48 Cal. 2d 408, 310 P.2d 15 (1957); People v. Schmidt, 10 Ill. 2d 221, 189 N.E.2d 726 (1957).

Holding that the defendant cannot withdraw his plea merely because he his re. ceived a more severe sentence than anticipated, even though the prosectitor may have assured him of leniency, are: Cortez v. United States, 337 F.2d 699 (9th Cir. 196-1); People v. Baldridge, 19 Ill. 2d 616, 169 N.E.2d 353 (1960).

47. Unpredictably harsh judicial responses to the plea bargain illustrate the fature of the current bargaining process to provide for pleas that are genuinely "knowing." The present judicial examination of the defendant is designed to insure that he is apprised of the legal consequences of his plea-of the scope of the rights he is forcgoing when he waives a trial, the nature of the offense to which he is pleading guilty, and the statutory disabilities, penal and otherwise, to which his conviction will subject him. See note 39 supra. Yet this information is less useful in the real calculations which precede a guilty plea than other information which is now unavailable to the defendant before the sentencing hearing, yet which a truly rational choice of plea should consider. See D. Newman, supra note 14 , at 208 . To assess the merits of any proposed plea bargain, the defendant seeks to forecast the precise consequences he can expect if he cont. sents to that bargain, if he insists on continuing plea negotiations, or if he declines to bargain and instead asserts his right to trial.

48. D. NewmaN, supra note 14 , at 43.

49. See J. Casper, Criminal Justice, The Consumer Perspegtive 3.54 (1972) 
such encounters do not take place, thereby clinging to the fiction that the sentencing hearing is the sole forum in which the sentencing decision is made..$^{50}$

From the defendant's perspective, plea bargaining lacks not only procedural regularity but also the personalization of punishment which advocates of individualized sentencing have sought. At no point do the judge and prosecutor manifest a recognition of the individual defendant's needs or articulate how the form of punishment they have applied will benefit either the defendant or the public.

Finally, the judge's peripheral role in plea bargaining leads many defendants to believe that the prosecutor dominates the criminal system and that the judge is virtually powerless. ${ }^{51}$ Understandably, these defendants may lose faith in the separation between the accusatorial and the adjudicative arms of the state which our system so earnestly strives to maintain. ${ }^{52}$

\section{An Alternative to the Current Bargaining Process}

No plea bargaining system can incorporate all the due process safeguards that trial adjudication has historically provided without sacrificing its administrative virtues. But the more modest goal of sentencing due process is well within the reach of a plea bargaining system. In order to realize that goal, the judge must reclaim his traditional responsibility for sentencing. He must replace the prosecutor as the chief source of the plea concessions that the defendant is offered.

Merely substituting the judge for the prosecutor, however, will not improve the bargaining process unless the present setting and method of plea bargaining are also altered. The judge must award plea concessions with the aid of full sentencing information about the defendant, and this information must be available at the outset, not the conclusion, of plea negotiations. Furthermore, the evaluation of this information, and the determination of the terms for the defendant's plea, must occur in an open advocacy proceeding which respects the procedural rights of the defendant and permits him to participate fully in the deliberation of his fate.

50. Most defendants assume the real purpose of both the official sentencing pro. cedure and judicial interrogation of the defendant is to protect the image of the system. A Connecticut defendant says of this inquiry: "If anybody's in the courtroom, yoll know, you gotta make a little show for them." J. Cisiren, supra note 49, at 3-39.

51. A Connecticut defendant expresses a typical vicw: "The person who runs the show is the prosecutor, you know." Interview with a Connecticut felony defendant, quoted in J. CASPER, supra note 49 , at V-16.

52. J. CASPER, supra note 49, at V-27-28, has perecptively analyzed the consequences of this loss of judicial independence. 


\section{A. The Pre-Plea Conference}

Such a proceeding could take the form of a pre-plea conference, conducted by a judge whose sole task is to oversee plea agreements. This conference could be modeled on the present sentencing hearing and draw elaborately on the resources and techniques which have been designed for sentencing.

Reconstructed along these lines, the pre-plea stage of the criminal process would include the following steps:

1. Once the prosecutor obtained an indictment or filed an information, his discretion to nolle prosequi would be suspended until the pre-plea conference. Prior to this conference, the judge would summarily decline to grant motions to dismiss, except on exceptional and highly circumscribed grounds. One such ground might be the prosecutor's decision to dismiss the entire proceeding against the defendant. Another might be the defendant's successful showing that his indictment was invalidly obtained.

2. Independent consultations between the defendant (or his counsel) and the prosecutor would be discouraged. If they occurred prior to indictment, they would have to be reported to the judge at the pre-plen conference so that he could determine their possible influence on that indictment's scope.

3. When the defendant first appeared before the court, he would be informed of his right to request a pre-plea conference. The judge would have no discretion to decline this request. Although the conference itself would be held only at the initiative of the defendant, the judge would have to reject any guilty plea until after the conference.

4. When the judge granted the defendant's motion for a pre-plen conference, he would simultaneously order pre-plea discovery to begin and instruct the probation office to begin its presentence investigation of the defendant.

5. When pre-plea discovery and the presentence report were completed, the contents of the presentence report would be disclosed to both parties and the discoverable evidence of both parties would be produced before the judge.

6. If the defendant filed any motions to suppress evidence, the judge would hear such motions before convening the pre-plea conference, and any evidence suppressed would be inadmissible at the conference as well as at trial. ${ }^{33}$ Suppression motions raised at the conference itself

53. In United States v. Schipiani, 435 F.2d 26 (2d Cir. 1970), the Second Circuit held that illegally obtained evidence can be admitted at a post-trial sentencing hearing if it is clearly reliable and is not obtained for the purpose of improperly influencing the sentencing judge. However, this decision was based on the court's belief that "applying 
would, where appropriate, lead to a stay of the proceedings pending a hearing on those motions.

7. Depending on the desire of the parties, the pre-plea conference would be held either in the judge's chambers or in open court. In either case, it would be fully transcribed.

8. At the conference there would be a full exploration of the following subjects: the factual and analytic accuracy of the presentence report; the nature of the culpability and criminal misconduct of the defendant as portrayed by the discoverable evidence; and the manner and duration of incarceration which is most consistent with the defendant's culpability and his prospects for rehabilitation. Should either of the parties wish to introduce witness testimony on any of these subjects, he would have to subpoena those witnesses in advance of the conference. The judge would have discretion to limit the number of such witnesses if administrative considerations so warranted. After beginning the conference, the judge would issue a stay to allow production of witnesses only in exceptional circumstances.

9. After the foregoing subjects were explored, both the prosecution and the defense would submit to the judge a proposed disposition of the defendant's case. Each proposed disposition would include, if appropriate, a recommendation for charge dismissal or reduction as well as a recommended sentence on each remaining charge.

10. At the conclusion of the conference, or after an appropriate interval, the judge would order two alternative dispositions of the defendant's case. The first would be imposed after conviction at trial, and would have been either selected from the dispositions submitted by counsel or formulated by the judge himself. It would include whatever charge reductions or dismissals the judge found appropriate and a sentence designation for each remaining charge. The second disposition would be imposed following a plea of guilty, and would be determined by reducing the total sentence designated for the post-trial disposition by a specific discount rate. This rate would be uniform for all defendants within a given jurisdiction and would embody the median plea concession necessary to induce an administratively acceptable volume of guilty pleas in that jurisdiction. ${ }^{54}$ The judge would be re-

the exclusionary rule for a second time at sentencing after having applied it once at trial would not add in any significant way to the deterrent effect of the rule." Id. at 28. Since most defendants who would move for a pre-plea conference would never stand trial, exclusion of illegally obtained evidence from that conference would be the only means of achieving the deterrent effect of the exclusionary rule in the vast majority of cases. Therefore, as would seem to follow from Schipiani's reasoning, such cridence should be excluded from the pre-plea process.

54. It would be difficult to set an effective rate of discount in advance of the actual operation of the pre-plea process. Its actual calculation would be a function of judicial 
quired to announce these alternative dispositions without recommendation or comment.

11. The defendant would then choose either to accept the terms stipulated by the judge for his guilty plea or to stand trial. Should he choose to plead guilty, the terms stipulated for that plea would automatically take effect when the plea was tendered. The judge would order the dismissal of charges as promised and impose the sentence announced. If he did not, the defendant would be permitted to withdraw his plea. ${ }^{55}$ When the defendant tendered his plea, the judge would make the same examination of the defendant that he conducts at present.

12. If the defendant decided to stand trial, he would be tried before a judge who had not participated in the pre-plea conference. The record of that conference would be privileged until the close of the trial, and both parties would be forbidden to introduce at trial statements or admissions that were made at the conference.

13. If the defendant were convicted after trial, the trial judge would receive the full record of the pre-plea conference together with the presentence report. In his discretion, he could hold a sentencing hearing, although the record of the pre-plea conference would probably make such a hearing unnecessary. In either case, the sentence he pronounced could not exceed the sentence which the pre-plea judge had designated for the defendant's conviction after trial. However, the trial judge would retain full discretion to sentence more leniently than the pre-plea judge if he thought it appropriate.

14. If the stipulated post-trial disposition had included the dismissal of any charges, these charges would be summarily dismissed before trial, with or without the prosecutor's approval. Moreover, after the pre-plea conference but before trial, the prosecutor would be unable to amend or abridge his indictment, except on a showing that neither measure had been taken to induce the defendant's guilty plea and that exceptional circumstances-such as newly discovered evidence-warranted some alteration in the charge against the defendant. Furthermore, should the judge permit a change in the indictment, he would also have to grant a subsequent defense motion to convene a new preplea conference.

15. The defendant would be able to reconsider his refusal to accept

experience, statistical reckoning and the relative congestion which each individual court docket faces.

55. The judge's failure to honor the announced terms for the defendant's plea would be easily demonstrable from the transcribed record of the pre-plea conference. 
the pre-plea terms at any time prior to the beginning of trial. If, before trial, he decided to plead guilty, the terms for that plea would automatically correspond to the guilty plea disposition which had been offered by the pre-plea judge. However, once his trial had begun, the defendant would no longer have automatic recourse to the pre-plea terms. Should he plead guilty while his trial was in progress, the trial judge would retain full sentencing discretion.

\section{B. Advantages of the Pre-Plea Conference}

This model for the bargaining process promises to improve plea bargaining in several ways.

First, it would curb the prosecutor's opportunity to abuse his charging power. The exercise of that power would be confined to the preplea conference; the judge would evaluate proposed charge reductions and dismissals in light of the larger background of the defendant's case and the cumulative plea concessions he may merit; and the judge would have an independent power to compel charge reductions and dismissals despite the objection of the prosecutor. ${ }^{00}$ Hence, the prosecutor would be unable to profit from overcharging the defendant.

Second, the pre-plea conference would stress the systematic use of sentencing information and sentencing criteria as the measure of plea concessions. The conference would be structured to stimulate the adversaries to debate the penological merits of the defendant's case-his actual culpability, the scope of his participation in the crime alleged, his criminal and personal history, and the social and individual interests which the application of various sanctions might advance or injure. As a consequence, defendants who plead guilty would receive sentences that are more uniform and less arbitrary.

Third, the conference would restrain illegally obtained evidence from influencing criminal dispositions. Under the current bargaining process, the prosecutor can use evidence derived from illegal police conduct to convince the defendant of the strength of the case against him. If the defendant is unaware of the infirmity of that evidence, and if the bargain is completed before suppression motions can be heard, the prosecutor can thus exploit the informality of the bargaining process to dilute the defendant's constitutional protections. Under the pro-

56. At least one jurisdiction, California, has already taken steps to accord the judge an independent dismissal power. See People v. Tenerio, 3 Cal. 3d 89, 89 Cal. Rptr. 249, 473 P.2d 993 (1970). 
posed pre-plea procedure, however, the court would complete any rcquested motions hearing before the conference, and evidence suppressed at that hearing would become inadmissible at the conference. This procedure would safeguard the defendant's constitutional rights and insure that police misconduct did not escape censure because of a hastily concluded plea bargain. ${ }^{57}$

As its fourth advantage, the pre-plea conference would discourngc the use of tactics wasteful of judicial time and resources. Neither defense nor prosecution would have any incentive to seek unnecessary continuances or contrived pre-trial motions in order to erode its opponent's bargaining strength. The conference would make a single, final determination of the plea concessions a defendant could expect to receive. Once these concessions were fixed, no amount of strategic maneuvering could alter them. The pre-plea conference thus promises a significant gain in efficiency to the criminal process.

Fifth, the pre-plea conference would permit the defendant to participate more rationally in the bargaining process. He would know more accurately the risks of standing trial and the potential benefits of a guilty plea. Moreover, because much of the prosecution's case would be discoverable prior to any-plea agreement, the defendant would be able to predict his fate at trial with greater certainty. ${ }^{58}$

Finally, the pre-plea conference would tend to equalize the tactical positions of affluent and indigent defendants. ${ }^{50}$ The reduction in wasteful bargaining tactics would favor indigent defendants, whose lack of resources precludes costly and elaborate bargaining strategies. Since the presentence report and pre-plea discovery would be the principal resources for this conference, preparation for it would probably not be significantly more burdensome for the public defender. And since this preparation and the hearing itself would impose modest time demands on its participants, it is unlikely that the overworked public defender would be at a serious disadvantage. Moreover, the pre-plea conference would permit the public defender to be a more zealous advocate for his client. The prosecutor would no longer be responsible for plea concessions, and thus the public defender's alleged deference to the prosecutor would not inhibit him in protecting his client's interests.

57. See note 53 supra.

58. One federal district court has already experimented with presplea discovery. For a discussion of its encouraging results, see Miller, The Omnibus Hearing-An Ex. periment in Federal Criminal Discovery, 5 San Diego L. REv. 293 (1968).

59. See pp. 294-95 supra. Nevertheless, the pre-plea conference would only minimizc, not eliminate, the bargaining disadvantage under which non-bailed defendants labor. 


\section{Evaluation of Possible Criticisms of the Pre-Plea Conference}

\section{Hazards of Judicial Intervention}

The most important objection to the pre-plea process would undoubtedly be directed at its principal feature: the central role it assigns to the judge in determining plea concessions and inducing guilty pleas. Active judicial participation in plea bargaining frequently has been opposed in the belief that it would aggravate the coercion already inherent in the bargaining process. ${ }^{\circ}$ Presumably, the prestige of the judge would overcome the defendant's voluntariness more readily than any equivalent prosecutorial pressure. ${ }^{.1}$

Judicial involvement in the bargaining process would shift the source of this coercion but not necessarily its degree. Plea bargaining is coercive largely because of the burden it places on the right to trial and the risk of hardship which the exercise of that right entails. At present, the prosecutor has the principal responsibility for persuading the defendant of the hardship he will face by asserting his right to trial; hence, he is the main source of the "coercion" which the process applies to the defendant. ${ }^{62}$ Concessions which the judge offers or penalties which he threatens would not necessarily be more coercive because he is the judge; their coerciveness depends primarily on whether they are more or less generous than the concessions the prosecutor would himself have offered.63 Since the concessions that the pre-plea judge offered would be more lenient for some defendants but less lenient for others, the contention that he will be uniformly more coercive is groundless.

Of course, to assert that judicial bargaining is not inherently more coercive does not preclude it from becoming so if the judge uses his

60. See United States ex rel. Elksnis v. Gilligan, 256 F. Supp. 244, 254 (S.D.X.Y. 1960): When a judge becomes a participant in plea bargaining he brings to bear the full force and majesty of his office. . . [H] is commitment has an all-pervasive and compelling influence in inducing the accused to yield his right to trial.

See also Scott v. United States, 419 F.2d 264, 273 (D.C. Cir. 1969); People v. Earegood, 12 Mich. App. 256 (Mich. Ct. App. 1968); Commonwealth v. Evans, 434 Pa. 52, 253 A.2d 689 (1969).

61. Judge Weinfeld in United States ex rel. Elksnis v. Gilligan, 256 F. Supp. 244, 255 (S.D.N.Y. 1966), explicitly distinguishes prosecutorial from judicial bargaining and finds the latter more coercive.

62. See generally Recent Development, supra note 5, at 1086:

[T] he prosecutor has many means not available to the judge of putting pressure upon the defendant .... [T] he "disparity of positions," in terms of powier over the accused, may be even greater between the prosecutor and the defendant than between judge and defendant.

63. At least one court has accepted this reasoning. See Shupe v. Sigler, 230 F. Supp. 601,606 (D. Neb. 1964): "Whether the court or prosecutor makes the threats or promises seems immaterial." 
authority to "browbeat" a defendant into accepting a plea bargain. However, the pre-plea conference would contain elaborate safeguards against such abusive judicial conduct: The judge would act as a neutral arbiter, presiding impartially over the presentation of facts and sentencing recommendations by both defense and prosecution. He would announce the alternative dispositions of the defendant's case without comment, expressing no opinion on their relative advantages. Direct pressure on the defendant to plead guilty would thus be forbidden.

Not only would the pre-plea conference guard against judicial coercion, it would also diminish the danger of prosecutorial coercion so immediate in the present plea bargaining process. The prosecutor would be forbidden to discuss plea terms with the defendant or his counsel outside of the conference itself. During the conference, the prosecutor's presentation would be limited in scope and addressed solely to the judge. Threats as well as more devious forms of persuasion by the prosecutor or the judge would be discernible from the record and would constitute grounds for reversal of a subsequent guilty plen conviction.

Another ground for opposition to judicial intervention in the bargaining process is the fear that it would make defendants doubtful that they would receive a fair trial. ${ }^{64}$ But this criticism is valid only if the judge with whom the defendant has bargained were the same judge who would later preside at his trial. In the proposed pre-plea procedure, this would not be the case. Skeptics have argued that even a trial judge who remained aloof from plea negotiations would be biased against a defendant who had refused a plea bargain offered by a fellow judge. ${ }^{65}$ However, it is surely more reasonable to anticipate that the trial judge who is aware that a defendant has declined a plea bargain would be all the more willing to credit the seriousness of his claim of innocence.

A third criticism of judicial intervention is that a judge who participated in the negotiation of a guilty plea could not later objectively examine the defendant to determine whether the plea was intelligently and voluntarily made. ${ }^{60}$ However, the effectiveness of that examination, as currently conducted, has been exaggerated. ${ }^{67}$ Neither prosecution nor defense now disclose candidly the full details of their plea

64. See ABA Standards, supra note 4.

65. For criticism of such a separation of trial and bargaining judges, see White, supra note 4, at $443 \mathrm{n} .73$, and ABA STANDARDs, supra note 4 , at 74 .

66. See, e.g., United States ex rel. Elksnis v. Gilligan, 256 F. Supp. 244, 254 (S.D.N.Y. 1966); Commonwealth v. Evans, 434 Pa. 52 (1969).

67. See p. 296 supra. 
negotiation. ${ }^{68}$ Moreover, since few plea bargains can be faulted for the negotiating tactics which produced them, ${ }^{80}$ only occasional guilty pleas now qualify as "involuntary" or "unknowing."

The pre-plea conference actually promises to safeguard the intelligence and voluntariness of the defendant's plea more scrupulously than the present process. A record would be available to substantiate allegations of official misconduct for appellate review. In addition, by reducing the uncertainty with which the defendant chooses among plea alternatives, the pre-plea process would facilitate pleas that are more genuinely knowing. ${ }^{0}$

Finally, the critics of judicial involvement argue that "bargaining judges" would detract from the judiciary's image as a neutral and principled arbiter. ${ }^{71}$ However, the present judicial posture in the bargaining process is far from aloof. If the judge regularly refused to accept the defendant's plea to a lesser offense, ${ }^{72}$ if he did not grant the prosecutor's motion to dismiss charges, ${ }^{73}$ or if he consistently disregarded the sentencing recommendations of the prosecutor, the incentives for plea bargaining would rapidly disappear.

68. At this late stage in the bargaining process, the interests of the prosecutor and defendant are no longer adverse. Instead, they have a joint commitment to the success of the plea bargain they have shaped. The parties therefore seek to present to the judge a facade of scrupulous regularity. See Note, Guilly Plea Bargaining supra note 5 , at 886 .

69. See, e.g., Shelton v. United States, 246 F.2d 571, 572 n.2 (5th Cir. 1957), rev'd on a confession of error, 356 U.S. 26 (1958), cited with approval in Brady v. United States, 397 U.S. 742, 755 (1970):

[A] plea of guilty entered by one fully aware of the consequences, including the actual value of any commitments made to him by the court, prosecutor, or his own counsel, must stand unless induced by threats (or promises to discontinuc improper harassment), misrepresentation (including unfulfilled or unfulfillable promises) or perhaps by promises that are by their nature improper as having no proper relationship to the prosecutor's business (e.g., bribes).

Prosecutorial conduct that will vitiate a guilty plea includes unreasonable threats, Machibroda v. United States, 368 U.S. 487 (1962); Pennsyliania ex rel. Herman v. Claudy, 350 U.S. 116 (1956); Walker v. Johnstone, 312 U.S. 275 (194I); overtures to the defendant without the presence or knowledge of his lawyer, Shupe v. Sigler, 230 F. Supp. 601 (D. Neb. 1964); Anderson v. North Carolina, 221 F. Supp. 931 (W.D.N.C. 1963); and reneging on earlier promises to the defendant, Santobello v. New York, 92 S. Ct. 495 (1971); Dillon v. United States, 307 F.2d 445 (9th Cir. 1962).

70. See note 47 supra.

71. White, supra note 4, at 453. See also Recent Decelopment, supra note 5, at 1089 ("Toleration of a procedure which leads defendants to think of the judge as just one more official to be "bought off is clearly not conducive to respect for the law" (footnote omitted)); Note, Unconstitutionality, supra note 1, at 1392-93.

72. In almost all jurisdictions, a defendant cannot tender a plea to a Jesser offense unless the judge accepts it. See, e.g., Conn. Gev. STAT. ANn. \$ $54-60$ (1958); MIN.. Stat. ANn. 630.30 (1946); Utah Code ANN. 77-24-8 (1953).

73. In most jurisdictions, the prosecutor cannot nolle prosequi a charge for which the defendant has been indicted without first obtaining judicial approval. See, e.s., Nev. Rev. Stat. \$ 178.510 (1956); OKLA. Stat. ANN., Title 22, \$ 815 (1960). On the prosecutor's dismissal power, see generally Note, Prosecutor's Discretion, 103 U. PA. L. REv. 1057, 1066-67 (1955). 
The judicial commitment to plea bargaining is also manifested in the policy of differential sentencing. It is universally acknowledged that, even absent an explicit agreement with the prosecutor, the judge will reward the defendant who pleads guilty with a reduced sentence. ${ }^{7 \cdot 4}$ And it is equally common, if less acceptable, for the judge to punish the defendant who has been convicted at trial by withholding the sentencing concessions he will extend to the defendant who has pled guilty. ${ }^{75}$

In the proposed pre-plea process, just as at present, the judge would be clearly committed to the persuasion of the great mass of defendants to forego their right to trial. However, both the defendant and the public would be more inclined to view his behavior as principled and consistent: His participation in the process would be formalized, his discretion prescribed by strict rules, and his role would be that of mediator between opposing interests rather than the advocate of the state against the accused. More importantly, the pre-plea process would restore the judge to his rightful place at the center of the criminal system, thus arresting the tendency of the current process to reduce him to a state of powerlessness.

\section{Volume of Guilty Pleas}

Another possible objection to the pre-plea process is that it would not elicit a sufficient number of guilty pleas, thereby defeating the principal rationale for plea bargaining. However, the discount rate would afford each jurisdiction a simple device for manipulating the proportion of guilty pleas it received; by lowering that rate to a suitable level, it would be able to insure a volume of guilty pleas equal to

74. For an empirical study of the pervasiveness of differential sentencing, sec Com. ment, The Influence of the Defendant's Plea on Judicial Determination of Sentence, 60 YALE L.J. 204 (1956). On differential sentencing generally, see Chalker, stupra note 88.

75. Many courts and commentators have distinguished between rewarding the gulty plea, which is a generally accepted practice and punishing the claim of innoccnce, which is generally disfavored.

The ABA STANDARDs, supra note 4, seem to accept this distinction when, at 1.8 , thcy approve judicial concessions to guilty pleaders but condemn harsh sentences for de. fendants who are convicted after trial.

The courts likewise have made much of this distinction. See United States $v$. Wilcy, 267 F.2d 453 (7th Cir. 1959), in which the sentence of a defendant convicted after trial was vacated for, among other reasons, the announced policy of the trial court to deny probation to those convicted after trial. See also l’cople v. Morales, 252 Call. App. 2d 537, 60 Cal. Rptr. 671 (1967).

Conversely, the judicial policy of rewarding guilty pleas with leniency has generally withstood appellate attack, See Dewey v. United States, 268 F.2d 124, 128 (8th Cir. 1959); People v. Guidan, 5 App. Div. 2d 975, 172 N.X.S.2d 640 (1958).

Nonetheless, the distinction seems more semantic than real. As Judge Levin pointed out in People v. Earegood, 12 Mich. App. 256, 268, 162 N.W. 802, 812 (1968): "Guilty pleaders cannot receive lighter sentences unless those convicted upon trial recelve heavier sentences-disparity there must be." 
-if not larger than-the volume of guilty pleas that the present system generates.

Of course, the prospect of an undiminished number of guilty pleas under the pre-plea procedure does not mean that the same defendants would be pleading guilty or that the same concessions would be awarded to any particular class of defendants. Defendants against whom the state's evidence is strong, who are indigent and represented by a public defender, or whose criminal conduct readily lends itself to overcharging would receive greater concessions than at present. To such defendants, the pre-plea judge would be more generous than the pragmatic prosecutor, who now concedes no more than is necessary to offset the improbable benefits anticipated from trial. On the other hand, the defendant against whom the state's evidence is weak would undoubtedly receive less generous terms for his guilty plea than he would at present and might as a consequence be more inclined to opt for trial. By affording a trial to such a defendant, the pre-plea process will result in more reliable distinctions between innocence and guilt. The net outcome would probably be a gain in sentencing equity without an unacceptable decline in the total number of guilty pleas.

\section{Self-incrimination}

A more serious criticism of the pre-plea conference is that it would jeopardize the Fifth Amendment privilege of the defendant who later stands trial by prematurely disclosing his case to the prosecutor and compelling admissions of guilt which would aid the prosecutor in gathering and organizing his evidence. Several features of the pre-plea conference, however, would mitigate this danger.

First, the presentence report could be limited to biographical information about the defendant and only such evidence of his alleged crime as would otherwise be discoverable. Second, the defendant would retain his usual Fifth Amendment privilege at the pre-plea conference; if he feared that his response to the inquiries of the judge would prejudice his case at trial, he would be free to remain silent. Third, the prohibition against use at trial of evidence submitted at the conference should prevent the prosecutor from gaining an overwhelming tactical advantage over the defendant. Finally, the trend toward pre-trial discovery $^{76}$ by the prosecution indicates that, in many jurisdictions, the

76. Advocating discovery by the prosecution are Rule 16 of Preliminary Draft of Proposed Amendments to Rules of Criminal Procedure for the United States District Courts, 48 F.R.D. 547 (1970), and the AMERICAN B.AR Associatios, Standaros Relatisic to Discovery aNd Procedure Before Trial (Approved Draft 1970), at 3.1 and 3.2. In Williams v. Florida, 399 U.S. 78 (1970), the Supreme Court held that at least some forms of compelled discovery by the prosecution are not forbidden by the Fifth Amendment. 
pre-plea conference would alter the timing but not the scope of the defendant's revelations to the prosecution.

However, these safeguards can never be completely effective. There is reason to doubt that an exclusionary rule can totally deter the prosecutor from using evidence at trial which has been indirectly derived from testimony presented at a confidential hearing. ${ }^{77}$ Perhaps more seriously, the defendant might succumb to the presumption of guilt which would pervade the conference. A defendant would be encouraged to present evidence in mitigation of his culpability, and such evidence is likely to be of considerable value to a prosecutor seeking to discover the exact circumstances of his crime. By penalizing the defendant who withholds potentially incriminating evidence with a harsher sentence, the pre-plea process would come perilously-although not impermissibly-close to diluting the Fifth Amendment privilege against self-incrimination..$^{78}$

Despite these hazards, it must be stressed that in the pre-plea process, just as in the present bargaining procedure, few defendants would ultimately stand trial..$^{70}$ The possibility of prejudice to the defendant who would go to trial must therefore be weighed against the benefits which the pre-plea conference could offer to the many defendants who

77. Under the proposed pre-plea process, the trial judge would cmploy the "Iruit of the poisonous tree" refinement of the exclusionary rule to suppress the derivative fruits of pre-plea testimony. Those fruits could be distinguished from validly admis. sible evidence by applying the "independent source," "inevitable discovery" and "attentattion" tests which the courts have evolved to aid their enforcement of the cxclusioniry rule. See Pitler, "The Fruit of the Poisonous Tree" Revisiled and Shepardized, 56 CAL1F. L. REv. 579, 621.30 (1968). However, these tests have been faulted for being awkward, arbitrary and inefficient. See, e.g., Note, Fruit of the Poisonous Tree-A Plea for Relevant Criteria, 115 U. PA. L. Rev. 1136 (1967).

78. The Supreme Court's recent decision in Williams v. Florida, 399 U.S. 78 (1970), strongly suggests that this feature of the pre-plea conference would not offend the Fifth Amendment. Rejecting the defendant's claim that his privilege against compelled self-incrimination had been violated, the Williams Court upheld a Florida statite re. quiring either disclosure of alibi witnesses in advance of trial or forfeiture of the op. portunity to present an alibi defense at trial. The dilemma in which that statute placed the defendant is analogous to the dilemma the pre-plea conference creates: thic de. fendant must either reveal evidence that may prove incriminating or risk the possibility of subsequent prejudice. Because, under the Florida procedure, the defendaut could choose to withhold evidence, the Williams Court reasoned that any disclosures he did decide to make were not "compelled" in violation of his Fifth $\Lambda$ mondment privilegc. 399 U.S. at 84 . Since the pre-plea conference contains a comparable element of strategic choice, similar logic would seem to purge it of any constitutional infirmity. Althotigh it may often be disadvantageous for him to do so, the pre-plea defendant is frec to withhold any testimony that might incriminate him at trial.

79. Moreover, there is reason to believe that the great majority of defendants-certain that their conviction is inevitable-view sentencing, rather than adjudication, as the stage of the criminal process that affects their interests most vitally. See Ohlin \& Remington, Sentencing Structure: Its Effect on Systems for the Administration of Criminal Justice, 23 LAw \& Contemp. ProB. 495, 499.500 (1958). Defendants who have this conception of the criminal process would probably not feel oppressed by a proccdure which weakened their chance for acquittal at trial but strengthened their ability to obtain equitable sentences. 
would tender a guilty plea. For those defendants, the pre-plea conference would be the only opportunity for a full revelation of the facts of their crimes, without which vital symbolic and penal functions would be left unperformed.

\section{Administrative Costs}

Also troubling are the apparent administrative costs of the preplea process. At first glance, the conference would seem to expend resources and time which neither the judge, the prosecutor nor the defendant can spare. However, while the pre-plea process would inevitably exact certain additional administrative costs, these costs would be smaller than its complicated machinery suggests.

The judge's duties at the conference would not be substantially more elaborate than those he now performs at the sentencing hearing. And since the pre-plea conference would usually obviate the need for a hearing, it would alter the timing, but not the magnitude, of the time required for each defendant's case. Moreover, in the interest of economy, one judge might be designated to take sole responsibility for presiding over pre-plea conferences. Arguably, this judge would be more efficient than the present trial judge, whose attention is divided among several cases, each at a different stage of development.

The pre-plea conference might expedite criminal proceedings in still another respect. Because it would eliminate the wasteful tactics which some prosecutors and defendants now employ, and because bargaining would be limited to a single session, both judge and prosecutor would be able to allocate their time more efficiently and systematically.

Nevertheless, the pre-plea conference would unavoidably make additional demands of the prosecutor and the public defender, who would be required to devote more preparation and thought to bargained dispositions. ${ }^{80}$ In the final analysis, this incremental burden must be recognized-and accepted-as the price of a more equitable and effective. criminal system. Even with such costs, the pre-plea conference would be far less demanding than the unabridged trial that would result from the total abolition of plea bargaining. Its requirements could be accommodated by modestly expanding the present resources of the prosecutor and public defender. The commitment of the additional funds and manpower for this purpose, if properly explained, should be politically feasible.

80. Despite this increased workload, judicial supervision and control, virtually nonexistent under the present system, could insure that the public defender diligently performed his duties under the restructured bargaining procedurc. 


\section{The Presumption of Guilt}

The final criticism the pre-plea process must face is that it would institutionalize a "presumption of guilt." By rewarding defendants who inculpate themselves and thus spare the state the expense of proving their guilt, the process arguably weakens the vitality of our constitutional commitment to the right to trial. Yet the present plea bargaining process embodies a presumption of guilt no less pervasive, for it imposes an equally stiff penalty on those defendants who choose to assert their innocence. It is arguable, of course, that this penalty is now imposed $s u b$ rosa and thus can be easily eliminated whenever our society devotes sufficient resources to its criminal system to afford a trial for every defendant; in contrast, the proposed pre-plea process would establish judicial machinery that might prove much harder to dismantle. Nonetheless, a massive commitment of resources to criminal justice is not presently a realistic prospect. Until it is, there can be little to praise in a system which espouses one theory of criminal procedure yet practices another.

\section{Conclusion}

The pre-plea process proposed by this Note is hardly a panacea for all the evils of plea bargaining. Even if it were instituted, judges, prosecutors and public defenders would continue to be more responsive to docket congestion than to the needs of the individual defendant. The indigent defendant would still feel pressured to agree to a plea bargain rather than linger in pre-trial confinement until his case came to trial. The innocent defendant might choose to plead guilty rather than risk the harsher punishment that he would face if he were convicted. And the guilty defendant who stands trial would still serve a longer sentence merely because he had exercised a right that the Constitution guarantees him.

The pre-plea process promises to minimize these inequities. It cannot eliminate them entirely because they are inherent in the very nature of plea bargaining. Complete reform of the plea bargaining process must inevitably await the complete abolition of plea bargaining. 